\title{
Does phosphate adsorption onto Saharan dust explain the unusual N/P ratio in the Mediterranean Sea?
}

\section{L'absorption des phosphates de poussières sahariennes explique-t-elle le taux N/P inhabituel en Méditerranée ?}

\author{
Céline Ridame $^{\mathrm{a}, *}$, Thierry Moutin ${ }^{\mathrm{b}}$, Cécile Guieu ${ }^{\mathrm{c}}$ \\ a Institut fur Meerskunde, Marine Biogeochemie, Düsternbrooker Weg. 20, 24105 Kiel, Germany \\ ${ }^{b}$ Laboratoire d'Océanographie et de Biogéochimie (LOB), Centre d'Océanologie de Marseille, Campus de Luminy Case 901, \\ 13288 Marseille cedex 9, France \\ ${ }^{c}$ Laboratoire d'Océanographie de Villefranche-sur-Mer (LOV), Quai de la Darse, BP 28, 06234, Villefranche-sur-Mer cedex, France
}

Received 25 March 2003; received in revised form 1 June 2003; accepted 11 June 2003

\begin{abstract}
A Saharan soil, considered as a proxy for Saharan aerosols, was used to perform radio-labelled phosphate adsorption experiments using ${ }^{33} \mathrm{PO}_{4}{ }^{3-}$ : leached particles were exposed to poisoned western Mediterranean seawater for varying lengths of time. The measured adsorption capacity of Saharan dust for phosphate was $0.13 \mu \mathrm{mol} \mathrm{g}{ }^{-1}$. Considering this value and an annual Saharan dust deposition of $12.5 \mathrm{t} \mathrm{km}^{-2} \mathrm{year}^{-1}$, we show that Saharan particles do not represent a significant sink for seawater phosphate in the western Mediterranean Sea. This result is in agreement with that determined from a similar approach conducted in the eastern basin. As a consequence, the unusual N/P ratio measured in the whole Mediterranean Sea (up to 29) cannot be explained by the adsorption process of seawater phosphate onto Saharan dust.

(c) 2003 Published by Éditions scientifiques et médicales Elsevier SAS.
\end{abstract}

\section{Résumé}

La fraction fine d'un sol composite saharien, considérée comme représentative de l'aérosol saharien en Méditerranée, a été utilisée dans des expériences de marquage au ${ }^{33} \mathrm{PO}_{4}{ }^{3-}$ afin de caractériser l'adsorption du phosphate présent dans la colonne d'eau, sur les poussières sahariennes. Pour cela, des poussières sahariennes lessivées ont été introduites dans de l'eau de mer empoisonnée, collectée en Méditerranée occidentale, durant 48 heures. La capacité d'adsorption des poussières sahariennes vis-à-vis du phosphate, ainsi mesurée, atteint une valeur de $0,13 \mu \mathrm{mol} \mathrm{g}{ }^{-1}$, à l'équilibre. En considérant cette valeur ainsi qu'un dépôt annuel de poussières sahariennes de $12,5 \mathrm{t} \mathrm{km}^{-2} \mathrm{yr}^{-1}$, nous avons montré que ces particules éoliennes ne constituent pas un puits significatif de phosphate en Méditerranée occidentale. Ce résultat est en accord avec une étude menée dans le bassin oriental. Par conséquent, le fort rapport N/P mesuré dans l'ensemble du bassin méditerranéen (jusqu'à 29) ne peut être expliqué par le processus d'adsorption du phosphate présent dans la colonne de l'eau, sur les poussières sahariennes.

(C) 2003 Published by Éditions scientifiques et médicales Elsevier SAS.

Keywords: Saharan dust; Adsorption; Phosphate; N/P ratio; Mediterranean Sea

Mots clés : Poussières sahariennes ; Adsorption ; Phosphate ; Rapport N/P ; Méditerranée

* Corresponding author.

E-mail address: cridame@ifm.uni-kiel.de (C. Ridame). 


\section{Introduction}

The intermediate and deep Mediterranean waters are characterized by a dissolved inorganic nitrogen/dissolved inorganic phosphorus (DIN/DIP, noted N/P) molar ratio, higher than the Redfield molar ratio of 16 and typical ocean values. This N/P ratio increases from 22 in the western part (Béthoux and Copin-Montégut, 1986) to around 24-29 in the eastern part (Krom et al., 1991; Béthoux et al., 2002), indicating that the eastern basin is strongly phosphorus limited and that the degree of P limitation increases from west to east (Krom et al., 1991; Moutin and Raimbault, 2002). In the western Mediterranean Sea, at the Dyfamed station, during the whole year, the N/P ratio below $70 \mathrm{~m}$ is always higher than the Redfield ratio (Marty et al., 2002). This supports the assumption that phosphate is the limiting nutrient of biological activity in this basin (Thingstad et al., 1998; Moutin and Raimbault, 2002).

Several hypotheses can be proposed to explain this anomalous N/P ratio observed in Mediterranean Sea. Looking at nutrient budgets, Béthoux and Copin-Montégut (1986) hypothesized that it may result from the biological fixation of atmospheric nitrogen. An alternative hypothesis is that the atmospheric deposition of nutrients may contribute to the anomalous N/P ratio (Herut and Krom, 1996; Kouvarakis et al., 2001). The N/P ratio measured in Mediterranean rainwater (60, 70 and 300, Migon et al., 1989; Herut et al., 1999a; Markaki et al., 2003, respectively) and in Mediterranean aerosol (152-261, Markaki et al., 2003) is higher than the Redfield ratio. A third hypothesis was put forward by Krom et al. (1991): phosphate (DIP) could be removed from seawater through inorganic adsorption processes onto mineral particles of atmospheric origin (Saharan dust). Indeed, Saharan aerosols are rich in iron hydroxides and clay minerals, which have a high affinity for DIP in seawater (Feely et al., 1990; Wheat et al., 1996; Bjerrum and Canfield, 2002). These authors suggested that such a mechanism may occur during the sedimentation of Saharan particles through the water column and, in particular, in deep waters. In this layer, there is no competition with the biological uptake and the phosphate content is relatively higher than in the surface waters.

The Mediterranean Sea is strongly influenced by atmospheric Saharan inputs and receives yearly considerable amounts of mineral particles. Loÿe-Pilot and Martin (1996) estimated a mean annual input of Saharan dust to the western Mediterranean of $12.5 \mathrm{t} \mathrm{km}^{-2}$ year $^{-1}$ for the period 19841994, with a very high interannual variability. Probably due to this very irregular temporal pattern, the Saharan dust deposition in the north-western Mediterranean Sea is about $4 \mathrm{t} \mathrm{km}^{-2}$ year $^{-1}$ (Ridame et al., 1999). This flux represents approximately $90 \%$ of the total atmospheric particulate fallout to the water column (Loÿe-Pilot and Martin, 1996). Wet deposition is considered to be a highly effective mechanism of dust deposition in the western Mediterranean Sea (LoÿePilot and Martin, 1996; Guerzoni et al., 1997). By comparison, in the eastern Mediterranean, an annual total dust depo- sition has been estimated to be $13 \mathrm{t} \mathrm{km}^{-2}$ year $^{-1}$ for the year 1992, with $56 \%$ in dry form (Kubilay et al., 2000). It has also been noted that Saharan particles represent a source of phosphate and dissolved iron for surface waters and may play a significant role in the biological activity in the Mediterranean Sea (Guieu et al., 2002a; Ridame and Guieu, 2002).

The aims of the present study were (i) to estimate, by use of ${ }^{33} \mathrm{PO}_{4}{ }^{3-}$ as a tracer, the adsorption capacity of the fine fraction of a Saharan soil, representative of the Saharan aerosols, for the DIP present in the western Mediterranean waters and (ii) to determine whether Saharan dust represents a significant sink for DIP in seawater, and thus may explain the unusually high N/P ratio recorded in the western Mediterranean Sea.

\section{Materials and methods}

The adsorption experiments were carried out on board the R/V La Thalassa during the Prosope cruise (productivity of pelagic oceanic systems). The cruise took place from 4 September (Agadir, Morocco) to 4 October (Toulon, France) 1999. Subsurface seawater (5 m depth) was collected on 1 October 1999, at the Dyfamed station (Fig. 1), located in the central Ligurian Sea $\left(43^{\circ} 25^{\prime} \mathrm{N}, 7^{\circ} 52^{\prime} \mathrm{E}\right)$, by use of a rosette equipped with $12-1$ Niskin bottles. The initial DIP concentration in the surface seawater was estimated according to the indirect method proposed by Moutin et al. (2002). This DIP concentration was low, less than $1 \mathrm{nM}$, which is characteristic of the Mediterranean surface seawater concentration during the oligotrophic period (Moutin et al., 2002).

The fine fraction of a composite Saharan soil was used to perform the adsorption experiments. Surface soil samples were collected under clean conditions, in southern Algeria, a region considered to be a significant source of Saharan dust for the western Mediterranean Sea (Guieu and Thomas, 1996). All samples were combined in order to obtain a composite Saharan soil. The fine fraction of this soil was shown to be representative of the Saharan aerosol carried over the western Mediterranean basin and will be designated hereafter by "the Saharan dust*". In particular, the grain size distribution $(<20 \mu \mathrm{m}$ and median diameter of $9 \mu \mathrm{m})$, the chemical and mineralogical compositions were very similar to those measured in the particulate phase of pure Saharan rains collected in Corsica (Guieu et al., 2002b; Ridame and Guieu, 2002). The clay fraction represented about $50 \%$ of the total mineralogical composition; the relative contents of total phosphorus and iron were on average $0.14 \%$ and $4.97 \%$ in weight, respectively.

For the present experiment, the Saharan dust* was leached in order to minimize the release of the phosphorus associated with the Saharan dust*. As Saharan particles reach the water column mainly by wet deposition in the western basin, ultra pure water (and not seawater) was chosen to leach the dust*: $50 \mathrm{mg} \mathrm{l}^{-1}$ were put into filtered ultra pure water $(\mathrm{pH} \sim 5.5)$ for $12 \mathrm{~h}$, then the suspension was filtered through a $0.4 \mu \mathrm{m}$ membrane (nuclepore polycarbonate). The use of a $0.4 \mu \mathrm{m}$ 


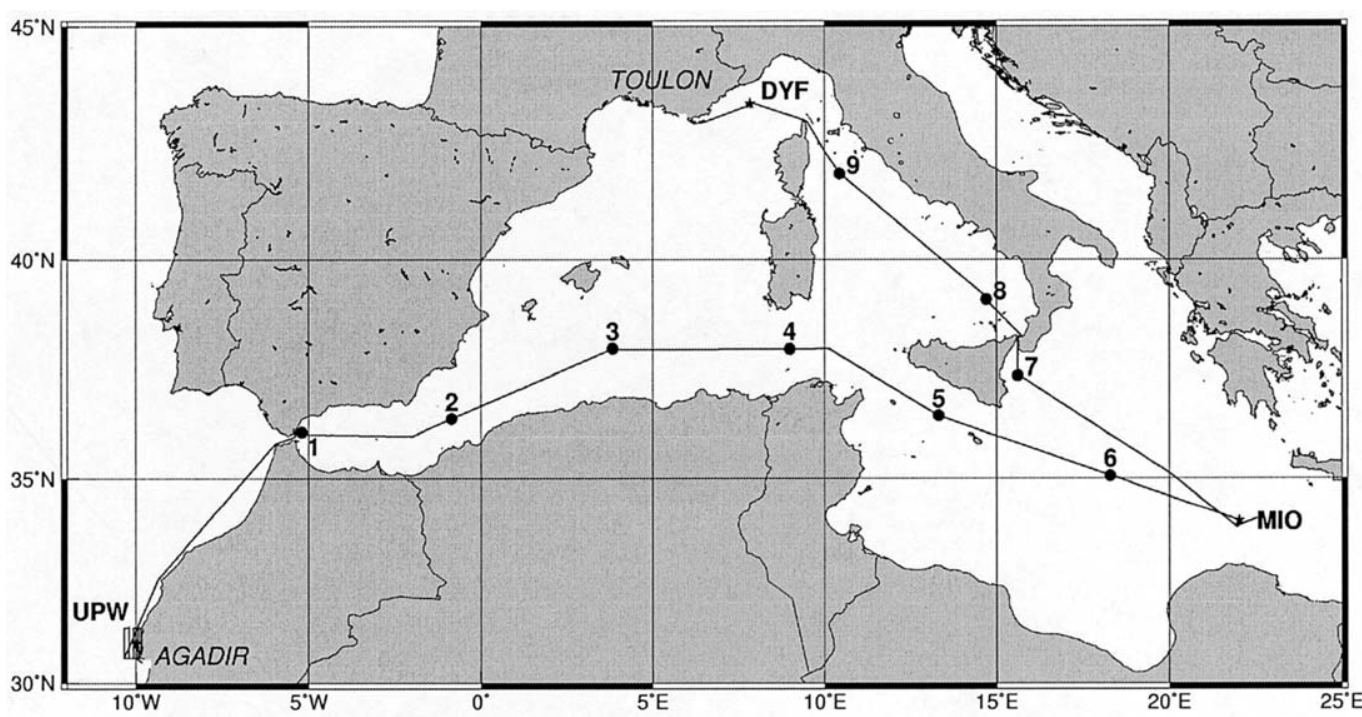

Fig. 1. PROSOPE cruise track showing the location of the station DYF (Dyfamed) where radio-labelled experiment was performed.

membrane could result in a loss of the very small particles. However, the grain size distribution in volume of this dust* has shown that the size fraction lower than $0.4 \mu \mathrm{m}$ represented less than $3 \%$ of the total volume of particles (Ridame, 2001; Guieu et al., 2002b). The filter was then dried $\left(40{ }^{\circ} \mathrm{C}\right)$ for $24 \mathrm{~h}$ and particles were collected and stored inside a desiccator.

Acid-washed polycarbonate bottles (Nalgene-1 1) were filled with $100 \mathrm{ml}$ of unfiltered seawater collected at Dyfamed station, poisoned with $\mathrm{HgCl}_{2}$ (final concentration in the sample $=24 \mathrm{mg} \mathrm{l}^{-1}$ ) to avoid biological uptake. After the dust* addition (5 and $96 \mathrm{mg} \mathrm{l}^{-1}$ d.w.), $25 \mu \mathrm{l}$ of a working solution containing a mix of non-radioactive $\mathrm{KH}_{2} \mathrm{PO}_{4}$ (concentration added in the samples $=300 \mathrm{nM}$ of stable phosphate-representative of the Mediterranean deep waters) and radiotracer ${ }^{33} \mathrm{PO}_{4}{ }^{3-}\left(20 \mu \mathrm{Ci}\right.$ of ${ }^{33} \mathrm{P}$-Amersham BF1003) were added to each bottle. The concentration of ${ }^{33} \mathrm{PO}_{4}{ }^{3-}$ was negligible compared to the stable concentration of DIP. The bottles were then placed in a deck incubator with circulating surface seawater for an incubation of $48 \mathrm{~h}$. Aliquots were sampled at $t=1.5,3.5,8.5,26$ and $48 \mathrm{~h}$ in duplicate and filtered through a $0.2 \mu \mathrm{m}$ membrane (polycarbonate Nuclepore). The control (no dust* addition) was used to quantify DIP adsorption onto particulate matter initially present in the seawater, the retention of ${ }^{33} \mathrm{P}$ on the filter and the bottle adsorption effect.

Radioactivity on filters was measured after the cruise at the LOB laboratory in Marseille, by a scintillation liquid counter (Packard 2100TR). The radioactivity of the total tracer added to the sample was counted in triplicate from $25 \mu \mathrm{l}$ of the working solution. The difference obtained between duplicates was less than $15 \%$. Although the mean activity measured on the control filters was less than $10 \%$ of that measured on the sample filters, this value was subtracted from the activity measured on the sample filters.
In this experiment, we assumed that the ${ }^{33} \mathrm{P}$ radiotracer and the stable DIP behaved in an identical manner, and thus, that the adsorbed fraction quantified from the radiotracer was representative of the non-radioactive DIP fraction actually adsorbed on to Saharan dust*.

\section{Results}

It was shown, from the control, that only a maximum of $0.04 \%$ of the added phosphate could be taken up from the poisoned seawater by other processes than adsorption onto Saharan dust* meaning that the DIP adsorption onto suspended particles initially present in surface water is negligible.

The percentage of phosphate adsorbed onto the mineral particles increased with the contact time of particles in seawater and with the amount of dust* introduced (Table 1). The adsorbed fraction onto mineral dust was relatively weak: only $0.2 \%$ and $4.3 \%$ of the phosphate added to the samples were removed from the solution by the particulate phase during the $48 \mathrm{~h}$ period of the experiment, for dust concentrations of 5 and $96 \mathrm{mg} \mathrm{l}^{-1}$, respectively (Table 1). The adsorption process was relatively rapid during the first $8 \mathrm{~h}$ of the experiment. After a contact time of $48 \mathrm{~h}$, the adsorption process tends towards a plateau, indicating that adsorption of DIP reached an equilibrium state.

The concentration of DIP (initially $300 \mathrm{nM}$ ) removed by the particles after a contact time of $48 \mathrm{~h}$ was 0.6 and $13 \mathrm{nM}$ for dust* concentrations of 5 and $96 \mathrm{mg} \mathrm{l}^{-1}$, respectively (Table 1).

The adsorption capacity, defined as the adsorbed amount of DIP onto particles per unit mass ( $\mathrm{g}$ ) of Saharan dust, was invariant with the amount of dust* introduced in seawater (Fig. 2). After a contact time of $48 \mathrm{~h}$, the adsorption capacity reached an equilibrium value of $0.13 \mu \mathrm{mol}$ DIP adsorbed per gram of dust*. 
Table 1

Mean percentage of ${ }^{33} \mathrm{P}$ adsorbed and mean DIP concentration adsorbed (nM) onto Saharan dust* for each duration of exposure (hours), for two leached dust* concentrations introduced into poisoned seawater: 5 and $96 \mathrm{mg} \mathrm{l}^{-1}$. The DIP concentration in the samples was $300 \mathrm{nM}$ (added with the stable phosphate). The adsorption percentage is defined as follows:

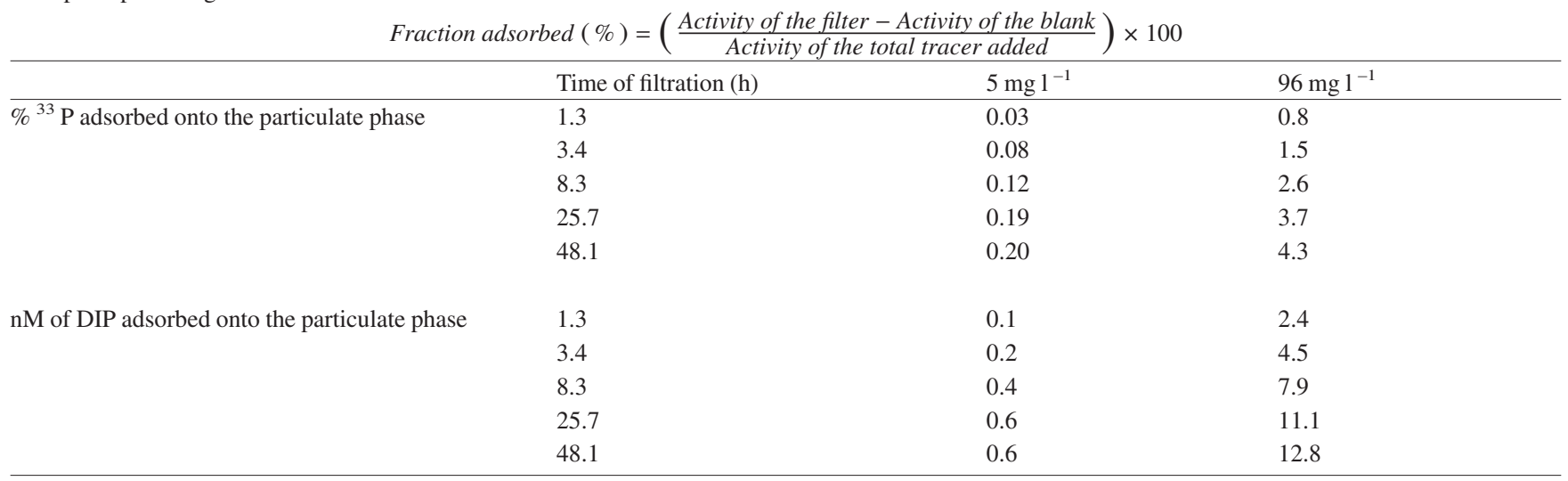

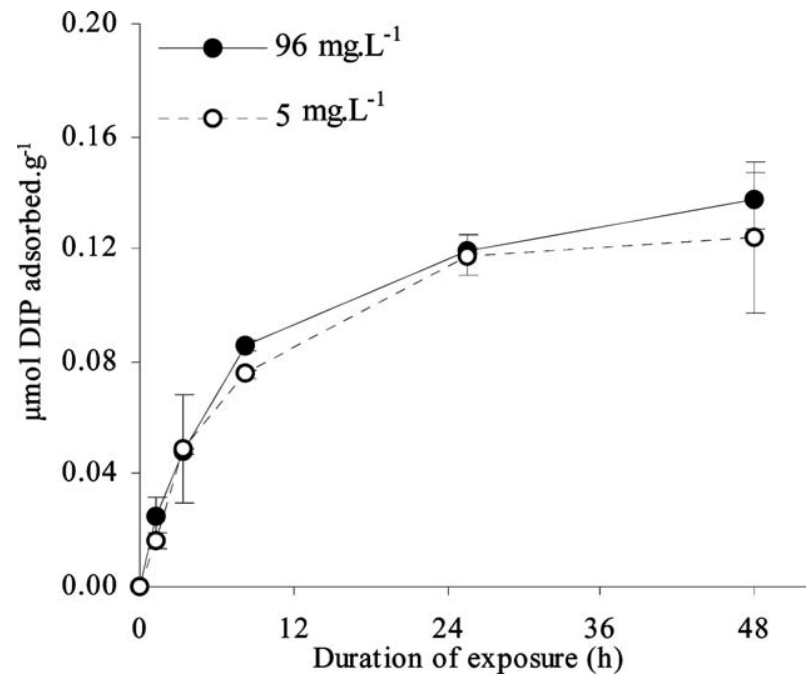

Fig. 2. Adsorption capacity (micromoles of DIP adsorbed onto particles per gram of Saharan dust*), as a function of exposure time (h), for two leached dust* concentrations: 5 and $96 \mathrm{mg} \mathrm{l}^{-1}$.

\section{Discussion and conclusion}

The adsorption capacity determined in our study was compared to that determined by Herut et al. (1999b), using loess from the Negev desert. In their radio-labelled experiment, $90 \mathrm{mg} \mathrm{l}^{-1}$ of previously leached loess were added to unfiltered and poisoned seawater (initial DIP concentration $=0.2 \mu \mathrm{M})$ spiked with ${ }^{32} \mathrm{PO}_{4}{ }^{3-}$. These particles were sieved through a $63 \mu \mathrm{m}$ mesh and had the following chemical characteristics: $\mathrm{P}$ total $=0.04 \%, \mathrm{Fe}$ total $=2.3 \%$ (in weight). These concentrations are much lower than those measured in the Saharan dust carried over the western Mediterranean basin (P total ranging from $0.25 \%$ to $0.4 \%$ in weight (Guerzoni et al., 1999), and on average $\mathrm{P}$ total $=0.08 \%$ and $\mathrm{Fe}$ total $=4.5 \%$ in weight (Guieu et al., 2002b)). The estimated adsorption capacity by these authors was about $0.15 \mu \mathrm{mol}$ DIP adsorbed per gram after a contact time of $5 \mathrm{~min}$ and $0.20 \mu \mathrm{mol}$ DIP adsorbed per gram at the equilibrium (about $2 \mathrm{~h}$ ). The kinetic behaviour of loess towards DIP is different to that observed in our study even though the particulate concentrations of dust and the initial DIP concentration were similar in both studies. For example, in our experiment, the adsorption capacity recorded after a contact time of $1.5 \mathrm{~h}$ is $0.02 \mu \mathrm{mol}$ DIP adsorbed per gram. During the kinetic reaction, the adsorption capacity calculated by Herut et al. (1999b) is higher by a factor of about 2 compared to our data. These differences between the two experiments could be the consequence of the use of two different types of dust (loess and composite Saharan soil) that have different chemical (mineralogy and total concentration of elements) and physical (grain-size distribution) properties.

The leaching step could influence the DIP adsorption. By decreasing the amount of iron hydroxides present on the surface of the particles, the leaching can decrease phosphate adsorption. However, the dissolution associated with the Saharan iron has been shown to be very low (Guieu et al., 2002a), and thus the leaching should not affect the adsorption process to a great extent. On the other hand, the leaching step could increase the DIP adsorption by decreasing the amount of phosphorus on the particles. In our experiment, the leached dust* used was representative of the Saharan particles collected in rainwater that reach the water column and sink to the deep waters of the western Mediterranean Sea. The phosphate concentration used in this work $(0.3 \mu \mathrm{M})$ was representative of the actual concentration in the intermediate and deep western Mediterranean waters (0.3-0.4 $\mu \mathrm{M}$, Béthoux et al. (1998); Marty et al. (2002)). In addition, no biological uptake of DIP could have out-competed the inorganic adsorption process. Therefore, we assume that the DIP adsorption capacity of the leached Saharan dust* determined in this study is representative of the actual adsorption process taking place in the waters of the western Mediterranean Sea.

The adsorption capacity of Saharan dust for DIP was used to estimate the potential sink that these particles represent for DIP in the western Mediterranean waters. In this calculation, we used a mean DIP concentration in the Mediterranean water column of $0.35 \mu \mathrm{M}$. For example, $5 \mathrm{mg} \mathrm{l}^{-1}$ of sinking leached Saharan dust* would remove only $0.65 \mathrm{nM}$ of DIP, 
which corresponds to $0.2 \%$ of the DIP present $(0.35 \mu \mathrm{M})$. This indicates that such concentration of leached Saharan dust* in the water column does not significantly modify the phosphate concentration in the waters. Consequently, Saharan particles do not represent a significant sink for DIP in the western Mediterranean waters. It has to be noted that such a particulate concentration $\left(5 \mathrm{mg} \mathrm{l}^{-1}\right)$ is much higher than the natural concentration expected in the water column. Therefore, this calculation leads to an overestimation of the DIP sink. As Saharan dust represents a source of phosphate for the water column, we calculated the phosphate concentration released by $5 \mathrm{mg} \mathrm{l}^{-1}$ of fresh Saharan dust* in seawater $(0.35 \mu \mathrm{M}$ of phosphate). For such a particulate concentration, about $30 \mathrm{nM}$ of DIP will be liberated in seawater (Ridame and Guieu, 2002). The concentration of adsorbed DIP accounts for about $2 \%$ of the concentration of DIP released by the dust. Consequently, the scavenging process of DIP onto Saharan dust in seawater is negligible compared to the dissolution process of Saharan phosphorus in seawater.

The time required to adsorb the necessary amount of DIP onto Saharan dust to reach a N/P ratio of 22 was calculated. The following parameters were considered: (i) a mean DIP concentration of $0.35 \mu \mathrm{M}$ in a water column of $1500 \mathrm{~m}$, (ii) a mean Saharan dust flux of $12.5 \mathrm{t} \mathrm{km}^{-2}$ year $^{-1}$ in the western basin (Loÿe-Pilot and Martin, 1996) and (iii) an adsorption capacity for Saharan dust of $0.13 \mu \mathrm{mol}$ DIP adsorbed per gram of Saharan dust (this study). To explain the difference observed between the N/P ratio of 22 and the Redfield ratio of 16 , the Saharan dust must scavenge $0.13 \mu \mathrm{M}$ of DIP. From our calculation, the scavenged DIP flux due to Saharan dust was estimated to $1.1 \times 10^{-6} \mu \mathrm{mol} \mathrm{l}^{-1}$ year $^{-1}$. Consequently, the time required to remove $0.13 \mu \mathrm{M}$ of DIP from the water column by adsorption onto Saharan dust would be on the order of 100000 years. This is much higher than the residence time of the deep water in the Algero-provencal basin ( 10-15 years, Andrié and Merlivat, 1988).

This calculation clearly demonstrates that the scavenging process of DIP onto Saharan dust*, considered as a proxy for Saharan aerosols, cannot explain the unusual N/P ratio measured in western Mediterranean Sea. Likewise, Herut et al. (1999b) have concluded that the process of DIP removal by loess particles is not able to explain the phosphate deficit in the eastern basin characterized by unusually high N/P ratio $(\sim 27-29)$.

Considering the entire Mediterranean Sea, the high N/P ratio in intermediate and deep waters (from 22 up to 29) cannot be explained by adsorption process of DIP from the water column onto Saharan dust, thus invalidating the hypothesis of Krom et al. (1991) for the Mediterranean.

An alternative explanation to this high N/P ratio in Mediterranean Sea, proposed by Béthoux and Copin-Montégut (1986), is that the biological fixation of atmospheric dinitrogen $\left(\mathrm{N}_{2}\right)$ may increase the DIN concentration in the water column, leading to an increase of this ratio. Some recent studies, based on the measurements of nitrogen stable isotope ratios in settling organic matter tend to confirm this assumption for the western Mediterranean basin (Kerhervé et al., 2001) and for the eastern Mediterranean basin (Sachs and Repeta, 1999). Pantoja et al. (2002) estimated that up to $20 \%$ of the nitrogen in the western basin and up to $90 \%$ in the eastern basin may derive from biological $\mathrm{N}_{2}$ fixation. The process of nitrogen fixation could be an essential key in explaining the high N/P ratio in Mediterranean waters. At the present time, the $\mathrm{N}_{2}$ fixation in Mediterranean Sea has not been experimentally quantified and specific studies must be undertaken to confirm if this contribution is significant to the nitrogen budget of the Mediterranean Sea. A recent study conducted by Markaki et al. (2003) demonstrated that the $\mathrm{N} / \mathrm{P}$ ratio measured in the atmospheric deposition in eastern Mediterranean Sea (up to 350) can exceed by a factor of up to 22 the Redfield N/P ratio of 16. This result confirms the hypothesis that the atmospheric inputs of nutrients ( $\mathrm{N}$ and $\mathrm{P}$ ) may reinforce the unusual N/P ratio in Mediterranean Sea. Then, the anomalous N/P ratio in Mediterranean may be the result of a combination between the process of nitrogen fixation and the contribution of atmospheric deposition of nutrients.

\section{Acknowledgements}

The work reported is part of the doctoral dissertation of C. Ridame (grant of the Ministère de l'Education Nationale, de la Recherche et de la Technologie) and is a contribution to the Proof Program Prosope. The captain, the crew of the RV Thalassa and H. Claustre are gratefully acknowledged. M. Mills and P. Croot are kindly thanked for their comments and their help with the English. We thank the reviewers for suggestions to improve the manuscript.

\section{References}

Andrié, C. Merlivat, L. 1988. Tritium in the western Mediterranean Sea during 1981 Phycemed cruise. Deep Sea Res. 35 (2), 247-267.

Béthoux, J.-P. Copin-Montégut, G. 1986. Biological fixation of atmospheric nitrogen in the Mediterranean Sea. Limnol. Oceanogr. 31 (6), 1353 1358.

Béthoux, J.-P. Morin, P. Chaumery, C. Connan, O. Gentili, B. Ruiz-Pino, D. 1998. Nutrients in the Mediterranean Sea, mass balance and statistical analysis of concentrations with respect to environmental change. Mar. Chem. 63 (1-2), 155-169.

Béthoux, J.-P. Morin, P. Ruiz-Pino, D.P. 2002. Temporal trends in nutrient ratios: chemical evidence of Mediterranean ecosystem changes driven by human activity. Deep Sea Res. II 49 (11), 2007-2016.

Bjerrum, C.J. Canfield, D.E. 2002. Ocean productivity before about $1.9 \mathrm{Gyr}$ ago limited by phosphorus adsorption onto iron oxides. Nature 417 , $159-162$.

Feely, R.A. Massoth, G.J. Baker, E.T. Cowen, J.P. Lamb, M.F. Krogslund, K.A. 1990. The effect of hydrothermal processes on midwater phosphorus distributions in the northeast Pacific. Earth Planet. Sci. Lett. 96 (3-4), 305-318.

Guerzoni, S. Chester, R. Dulac, F. Herut, B. Loÿe-Pilot, M.-D. Measures, C. Migon, C. Molinaroli, E. Moulin, C. Rossini, P. Saydam, C. Soudine, A. Ziveri, P. 1999. The role of atmospheric deposition in the biogeochemistry of the Mediterranean Sea. Prog. Oceanogr. 44 (1-3), 147-190. 
Guerzoni, S. Molinaroli, E. Chester, R. 1997. Saharan dust inputs to the western Mediterranean Sea: depositional patterns, geochemistry and sedimentological implications. Deep Sea Res. 44 (3-4), 631-654.

Guieu, C. Bozec, Y. Blain, S. Ridame, C. Sarthou, G. Leblond, N. 2002a. Impact of high Saharan dust inputs on dissolved iron concentrations in the Mediterranean Sea. Geophys. Res. Lett. 29 (19), 1911.

Guieu, C. Loÿe-Pilot, M.D. Ridame, C. Thomas, C. 2002b. Chemical characterization of the Saharan dust end-member: some biogeochemical implications for the western Mediterranean Sea. J. Geophys. Res. 107 (15), 4258.

Guieu, C. Thomas, A.J. 1996. Saharan aerosols: from the soil to the ocean In: Chester, R. (Ed.), The impact of desert dust across the Mediterranean. Kluwer Academic Publishers, pp. 207-216

Herut, B. Krom, M.D. 1996. Atmospheric input of nutrients and dust to the SE Mediterranean. In: Chester, R. (Ed.), The Impact of Desert Dust Across the Mediterranean. Kluwer Academic Publishers, pp. 349-358.

Herut, B. Krom, M.D. Pan, G. Mortimer, R. 1999a. Atmospheric input of nitrogen and phosphorus to the Southeast Mediterranean: sources, fluxes, and possible impact. Limnol. Oceanogr. 44 (7), 1683-1692.

Herut, B. Zohary, T. Robarts, R.D. Kress, N. 1999b. Adsorption of dissolved phosphate onto loess particles in surface and deep Eastern Mediterranean water. Mar. Chem. 64 (4), 253-265.

Kerhervé, P. Minagawa, M. Heussner, S. Monaco, A. 2001. Stable isotopes $\left({ }^{13} \mathrm{C} /{ }^{12} \mathrm{C}\right.$ and $\left.{ }^{15} \mathrm{~N} /{ }^{14} \mathrm{~N}\right)$ in settling organic matter of the northwestern Mediterranean Sea: biogeochemical implications. Oceanol. Acta 24 (Suppl), S77-S85.

Kouvarakis, G. Mihalopoulos, N. Tselepides, A. Stavrakaki, S. 2001. On the importance of atmospheric inputs of inorganic nitrogen species on the productivity of the eastern Mediterranean Sea. Global Biogeochem. Cycles 15 (4), 805-817.

Krom, M.D. Kress, N. Brenner, S. Gordon, L.I. 1991. Phosphorus limitation of primary productivity in the eastern Mediterranean Sea. Limnol. Oceanogr. 36 (3), 424-432.

Kubilay, N. Nickovic, S. Moulin, C. Dulac, F. 2000. An illustration of the transport and deposition of mineral dust onto the eastern Mediterranean. Atmos. Environ. 34, 1293-1303.

Loÿe-Pilot, M.-D. Martin, J.-M. 1996. Saharan dust input to the western Mediterranean: an eleven years record in Corsica. In: Chester, R. (Ed.), The Impact of Desert Dust Across the Mediterranean. Kluwer Academic Publishers, pp. 191-199.
Markaki, Z. Oikonomou, K. Kocak, M. Kouvarakis, G. Chaniotaki, A. Kubilay, N. Mihalopoulos, N. 2003. Atmospheric deposition of inorganic phosphorus in the Levantine Basin, Eastern Mediterranean: spatial and temporal variability and its role in seawater productivity. Limnol. Oceanogr. 48 (4), 1557-1568.

Marty, J.-C. Chiaverini, J. Pizay, M.D. Avril, B. 2002. Seasonal and interannual dynamics of nutrients and phytoplankton pigments in the western Mediterranean Sea at the DYFAMED time-series station (1991-1999). Deep Sea Res. II 49 (11), 1965-1985.

Migon, C. Copin-Montegut, G. Elegant, L. Morelli, J. 1989. Atmospheric input of nutrients to the coastal Mediterranean area. Biogeochemical implications. Oceanol. Acta 12 (2), 187-191.

Moutin, T. Raimbault, P. 2002. Primary production, carbon export and nutrients availability in western and eastern Mediterranean Sea in early summer 1996 (MINOS cruise). J. Mar. Syst. 33-34, 273-288.

Moutin, T. Thingstad, T.F. Van Wambeke, F. Marie, D. Slawyk, G. Raimbault, P. Claustre, H. 2002. Does competition for nanomolar phosphate supply explain the predominance of the cyanobacterium Synechococcus? Limnol. Oceanogr. 47 (5), 1562-1567.

Pantoja, S. Repeta, D.J. Sachs, J.P. Sigman, D.M. 2002. Stable isotope constraints on the nitrogen cycle of the Mediterranean Sea water column. Deep Sea Res. 49 (9), 1609-1621 Part I.

Ridame, C. 2001. Rôle des apports atmosphériques d'origine continentale dans la biogéochimie marine : impact des apports sahariens sur la production primaire en Méditerranée. Université Paris 6 (Pierre et Marie Curie) $253 \mathrm{p}$.

Ridame, C. Guieu, C. 2002. Saharan input of phosphate to the oligotrophic water of the open western Mediterranean Sea. Limnol. Oceanogr. 47 (3), 856-869.

Ridame, C. Guieu, C. Loÿe-Pilot, M.-D. 1999. Trend in total atmospheric deposition fluxes of aluminium, iron, and trace metals in the northwestern Mediterranean over the past decade (1985-1997). J. Geophys. Res. 104 (23), 30127-30138.

Sachs, J.P. Repeta, D.J. 1999. Oligotrophy and nitrogen fixation during eastern Mediterranean sapropel events. Science 286, 2485-2488.

Thingstad, T.F. Zweifel, U.L. Rassoulzadegan, F. 1998. P limitation of heterotrophic bacteria and phytoplankton in the northwest Mediterranean. Limnol. Oceanogr. 43 (1), 88-94.

Wheat, C.G. Feely, R.A. Mottl, M.J. 1996. Phosphate removal by oceanic hydrothermal processes: an update of the phosphorus budget in the oceans. Geochim. Cosmochim. Acta 60 (19), 3593-3608. 